\title{
Play and Preschool Children Who Are Deaf: A Review of the Literature
}

\author{
Millicent Musyoka \\ Lamar University, Beaumont, USA \\ Email: mmusyoka@lamar.edu
}

How to cite this paper: Musyoka, M. (2018). Play and Preschool Children Who Are Deaf: A Review of the Literature. Creative Education, 9, 1794-1807. https://doi.org/10.4236/ce.2018.912130

Received: June 13, 2018

Accepted: September 7, 2018

Published: September 10, 2018

Copyright $\odot 2018$ by author and Scientific Research Publishing Inc. This work is licensed under the Creative Commons Attribution International License (CC BY 4.0).

http://creativecommons.org/licenses/by/4.0/

\begin{abstract}
The purpose of this study was to provide a narrative review of the literature of studies on deaf children play. Electronic searches of databases including EBSCOhost, ERIC, Deaf Education related journals, and Google Scholar were undertaken using terms such as deaf play, deaf play and literacy, deaf play and school and deaf play and language, deaf play and cognition. Relevant articles on the deaf children play extracted were synthesized narratively. The results of the analysis were interpreted using descriptive analysis, percentages, frequencies and emerging themes. The data showed most of the studies focused on comparing deaf children play behaviors to those of the hearing peers. Findings on deaf children social and cognitive play were inconsistent. Several issues in this analysis point to implications for future research, teacher preparation and teacher intentionality in the implementation of play in early childhood education (ECE) classrooms.
\end{abstract}

\section{Keywords}

Deaf, Children Play, Deaf Children Play, Deaf Children Interactions

\section{Introduction}

Supporting language and literacy development among young children who are deaf is a critical issue for deaf educators (Allen, Letteri, \& Choi, 2014; Golos \& Moses, 2013; Gray, 1995; Mayer, 2007; Musyoka, 2015; Williams, 2004). Early language access is reported as a significant factor that creates literacy challenges and literacy gaps among most of the students who are deaf (Freel et al., 2011; Myers et al., 2010). Attending to literacy needs of students who are deaf is critical because the previous literature shows that most them tend to graduate reading and fourth-grade level (Allen, 1986; Traxler, 2000; Furth, 1966; Trybus \& Karchmer, 1972). 
Previous works identify about $90 \%$ of children who are deaf are from hearing families, (Moores, 1987; Mitchell \& Karchmer, 2004). Consequently, a possibility that most of these children may not have an opportunity for early access to comprehensible language input is a visual language. Lack of a strong language base from home explains why most children who are deaf are reported having no strong language base by the time they start school (Williams, 1991, Williams, Kantor, \& Pinnell, 1992). Consequently, ECE programs with students who are deaf need to identify strategies they can implement in their classroom to model and support language while supporting emergent literacy development.

Children's play has become increasingly relevant because of its role in supporting language and literacy development (Bergen, 2002; Bergen \& Mauer 2000; Christakis, Zimmerman, \& Garrison, 2007; Christie \& Enz 1992; Pelegrini, 1980; Smith, 2010; Vukelich, 1994; Weisbert, Zosh, Hirsh-Pasek, \& Golinkoff, 2013). Children play is an important aspect of ECE classrooms (Ashiabi, 2007; Cheng, 2012; Fisher, Hirsh-Pasek, Golinko, Singer, \& Berk. 2009; Lee, 2006; Lynch, 2015; Quance, Lehrer, \& Stathopoulos, 2008). The NAEYC consensus is that play is an important aspect of Developmentally Appropriate Practice (DAP) should be provided in ECE (Bredekamp \& Copple, 1997; NAEYC, 2009). Given its importance, understanding play among young children who are deaf and how to integrate it to support language and literacy development is critical for educators in ECE programs.

\section{Purpose of the Review}

The goal of this paper was to document a narrative review of the literature of studies on the play of children who are deaf. According to Onwuegbuzie, Leech and Collins (2012), a review of the literature provides information on previous research work and the gaps in research to be addressed without redundant replication. This paper seeks to examine the extent, trends, the research topics and research methodologies employed in the studies on play of children who are deaf. One advantage of this review is that it enables educators to learn about the research evidence that can be translated into practice and identify the gaps that require more research.

\section{Methodology}

For this review, content analysis was used to study empirical documentation and answer the proposed research questions. Content analysis is used to analyze written, verbal or visual information, artifacts, and pictures qualitatively and quantitatively (Creswell, 2012). Content analysis was used in previous literature reviews (Jamaludin, Alias, \& DeWitt, 2015; Maschi, Baer, \& Turner, 2011; Zainuddin \& Halili, 2016).

\section{Research Questions}

The following research questions guided the literature review: 
1) What were research designs employed in research on the play of children who are deaf?

2) Who are the targeted population and participants?

3) What is the trend of the research in research on the play of children who are deaf?

4) What is the focus of the research in research on the play of children who are deaf?

5) How are language and literacy represented in research on the play of children who are deaf?

\section{Articles Reviewed Selection}

The present study identified 55 peer-reviewed scholarly articles and included 32 articles in the review. A search of the relevant literature was undertaken using these databases Education Resources Information Center (ERIC), PsycINFO, PsycARTICLES, EBSCOhost, Academic Search Complete, Dissertations Abstracts, JSTOR and ProQuest, and search engine of Google Scholar. The principal search terms used included: play and deaf, social play and deaf, cognitive play and deaf, classroom play and deaf, indoor play and deaf, outdoor play and deaf.

The review articles were filtered using the following criteria:

1) Inclusion criteria included:

a) Types of participants: children who are deaf ages 3 - 8-year-old; Early Childhood Education (ECE) is from Birth through Age 8.

b) Research setting: school/classroom.

c) Empirical study: Qualitative, quantitative or mixed research studies.

d) Publication: full-text review studies published.

e) Language: English.

2) Exclusion criteria included:

a) Studies focusing on the play outside of school.

b) Studies focusing on hearing children only.

c) Lack of access to the full text.

d) Studies not empirical and did not include the participants' description, methodology or the findings.

e) Publications not in English.

Given the lack of research exclusively focused on the play of children who are deaf in USA the search was widened to include analysis from countries outside the USA. The flowchart in Figure 1 illustrates the articles selection process.

\section{Reliability}

To increase reliability, a second coder who has the same background in deaf education assisted in coding. Disagreed issues were discussed and coded after both coders reached a consensus.

\section{Findings and Discussion}

The major themes that emerged from the articles reviewed included. 


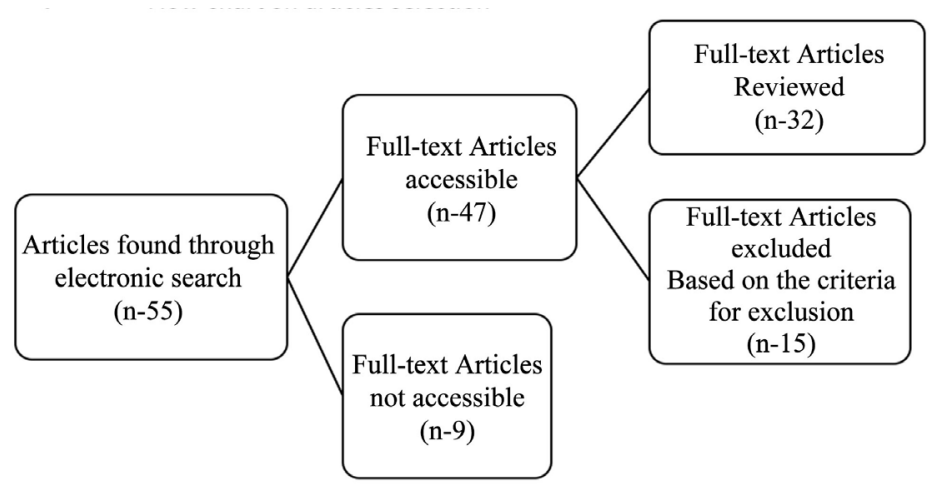

Figure 1. Flow chart on articles selection.

\subsection{Research Designs}

This review found that the most frequently used methodologies were the quantitative approach (64.5\%). A total of 21 studies selected used a quantitative research design. It is interesting to note that majority of the quantitative studies used a comparative methodology. The goal was to compare play of children who are deaf to that of their hearing peer (Arnold \& Trembly, 1979; Bobzien, Richels, Raver, Hester, Browning, \& Morin, 2013; Brackett \& Henniges, 1976; Brown, Prescott, Rickards, \& Peterson, 1997; Cornelius \& Hornett 1990; Darbyshire 1977; Deluzio \& Girolametta, 2011; Esposito \& Koorland, 1989; Gatty 1990; Higginbotham \& Baker 1981; Kretschmer 1972; Lederberg, Ryan, \& Robbins, 1986; Levine, 1993; Levy-Shiff \& Hoffman, 1985; Mann, 1984; McKirdy \& Black, 1982; Minnet, Clark \& Wilson, 1994; Quintas, Curti, Goulart, \& Chiari, 2009; Vandell \& George 1981). Other quantitative studies investigated the relationship between language and play (Casby \& McCormack 1985; Lederberg, 1991; Quittner, Cejas, Wang, Niparko, \& Barker, 2016; Schirmer, 1989). There was one experimental study (Pataki, Metz, \& Metz, 2014) and one longitudinal study (Quittner et al., 2016).

Other studies reviewed were qualitative descriptive studies that focused on play behavior, interactions and language use (Brunberg, 2005; Chapel, 2005; O'Connor, 1994; Messenheimer-Young \& Kretschmer, 1994; Musyoka, 2015a, b; Bilir \& Bal, 1995). Figure 2 shows the frequency of the various type of research methods used in the 32 selected articles.

The articles reviewed were published between 1971-2016. The trend of the research methodologies used in research on the play of children who are deaf showed that the research design used mostly in the period between 1970 and 1999 was predominantly quantitative methods. Articles published after 1980 employed qualitative research method. See Figure 3. For the methodological trend in research on the play of children who are deaf.

Although the research setting varied most of the studies were conducted in integrated or inclusive school play setting with hearing students (Arnold \& Trembly 1979; Bobzien et al., 2013; Brown et al., 1997; Brackett \& Henniges, 1976; O'Connor, 1994; Cornelius \& Hornett, 1990; Deluzio \& Girolametta, 2011; Esposito \& Koorland, 1989; Gatty, 1990; Levy-Shiff \& Hoffman, 1985; Vandell \& 


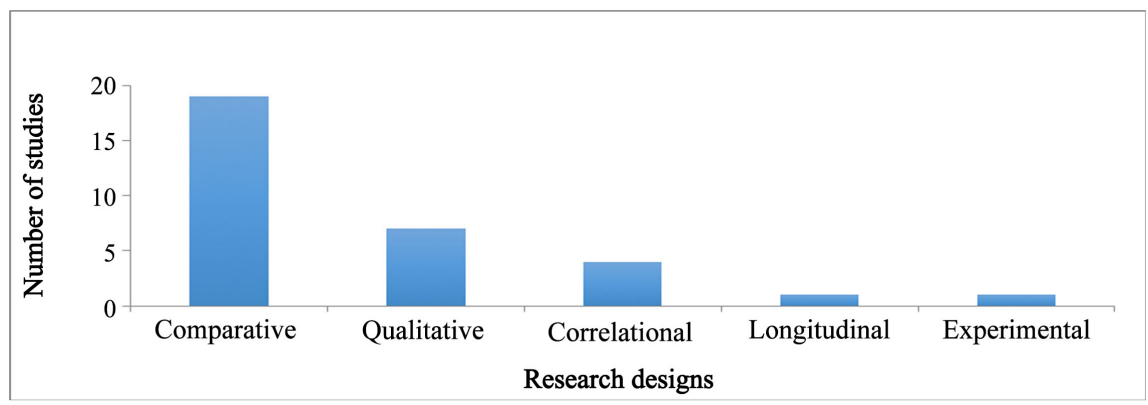

Figure 2. Frequencies on research designs employed.

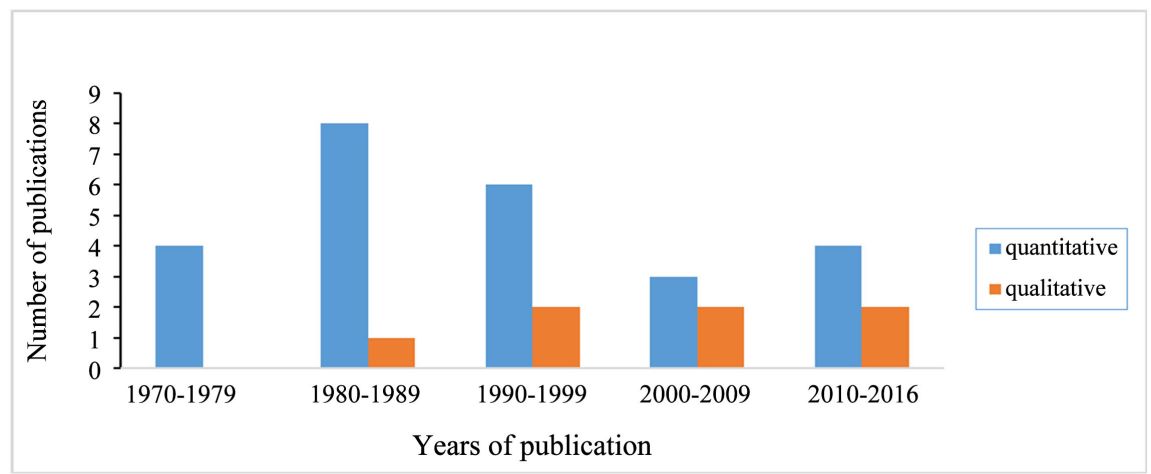

Figure 3. Trend of research methods used on deaf children play studies.

George, 1981; Mann, 1984, McKirdy \& Black, 1982; Messenheimer-Young \& Kretschmer, 1994; Minnett, et al., 1994; Bilir \& Bal, 1995; Vandell \& George 1981). Other research settings included self-contained or segregated settings (Higginbothan \& Baker, 1981; Lederberg, 1991; Mevine, 1993; Musyoka, 2015, a, b). A few studies were conducted in clinical settings (Casby \& McCormack 1985; Chapel, 2005; Darbyshire, 1977; Kretchmer, 1972; Lederberg, Ryan, \& Robbins, 1986; Quittner et al., 2016; Schirmer, 1989; Sisco, Kranz, Lund, \& Schwartz, 1979). Of all the studies reviewed, only three studies were deaf children observed playing both integrated and segregated educational settings (Brunnberg, 2005; O'Connor, 1994; Cornelius \& Hornett, 1990).

\subsection{Targeted Population}

Regarding participants, all participants in this study were children of different ages, (between 3 - 8 years) with various hearing loss levels and communication modalities. Some studies had participants without detailed information as to what their hearing level was or the type of communication mode. The majority of the participants' communication modalities was identified as oral or verbal (Arnold \& Trembly 1979; Bobzien, et al., 2013; Brackett \& Henniges, 1976; Brown, Prescott, Rickards, \& Peterson, 1997; O’Connor, 1994; Darbyshire, 1977; Deluzio \& Girolametta, 2011; Esposito \& Koorland, 1989; Gatty, 1990; Higginbotham \& Baker, 1981; Kretschmer, 1972; Levy-Shiff \& Hoffman, 1985; Mann, 1984; Messenheimer-Young \& Kretschmer, 1994; Minnett, et al., 1994). Oral or 
verbal communication was noted to occur mostly to students attending integrated or inclusive educational settings.

Another communication modality reported in the studies of play of children who are deaf play was sign language (Casby \& McCormack 1985; Chapel, 2005; Pataki, Metz, \& Metz, 2014; Quittner et al., 2016; Schirmer, 1989; Bilir \& Bal, 1995). Some students had opportunities to use either signing or oral communication depending on the play context and play partners (Brunnberg, 2005; Cornelius \& Hornett, 1990). Also, some studies involved children who are deaf using total communication or simultaneous communication (Lederberg, Ryan, \& Robbins, 1986; Levine, 1993; McKirdy \& Black, 1982; Schirmer, 1989; Vandell \& George, 1981). Only two studies indicated the children were ASL/English bilinguals (Musyoka, 2015a, b).

\subsection{Research Trend}

The review showed an increase in the number of articles published that focus on the play of children who are deaf in more recent years (see Figure 4). The increase suggests a growing interest in research on children's play that existed in the period between 1980 and 1999. Also, the review showed a significant decline in research on play of children who are deaf between 2000-2009. Despite the recent increase from 2010, there is still a need to examine play of children who are deaf and to focus on the current needs of children who are deaf and are ASL/English bilingual bimodal and those with cochlear implants.

\subsection{Research Focus}

The data analysis identified six focus area including; play behaviors, communication during play, language and play, play interactions, play and literacy and play and therapy. Figure 5 shows the number of studies and the research focus.

Most of the studies focused on the nature of play behavior $(32 \%, n=14)$ and play interactions $(30 \%, \mathrm{n}-13)$. Studies that focused on play behaviors attended to both social and cognitive play behaviors (Arnold \& Trembly, 1979; Brown, et al., 1997; Brown et. al., 2000; O’Connor, 1994; Cornelius \& Hornett, 1990; Darbyshire, 1977; Esposito \& Koorland, 1989; Gatty, 1990; Higginbotham \& Baker, 1981; Kretschmer, 1972; Levine, 1993; Levy-Shiff \& Hoffman 1985; Mann, 1984; Musyoka, 2015; Quintas et al., 2009). Most studies examined the nature of social play interactions (Brown, et al., 1997; Brunnber, 2005; Deluzio \& Girolametta, 2011; Esposito \& Koorland, 1989; Kretchmer, 1972; Lederberg, 1991; Lederberg Ryan \& Robbins, 1986; Levine, 1993: Levy-Shiff \& Hoffman 1985; McKirdy \& Black, 1982; Messenheimer-Young \& Kretschmer, 1994; Minnett, et al., 1994; Musyoka, 2015; Vandell \& George, 1981). More studies focused on communication $(19 \%, n=8)$ compared to those that focused on language $(14 \%, n=6)$. Studies that focused on language mostly examined the association between play and language (Casby \& McCormack, 1985; Cornelious \& Hornett, 1990; Lederberg, 1991; Quittner et al., 2016, Schirmer, 1989). There were only two studies that 


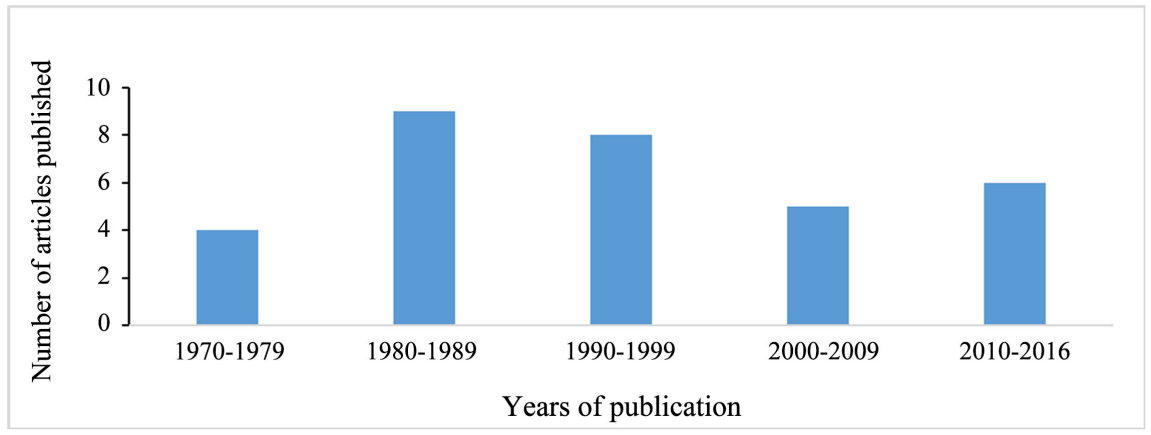

Figure 4. The trend of Deaf children play research from 1970 to date.

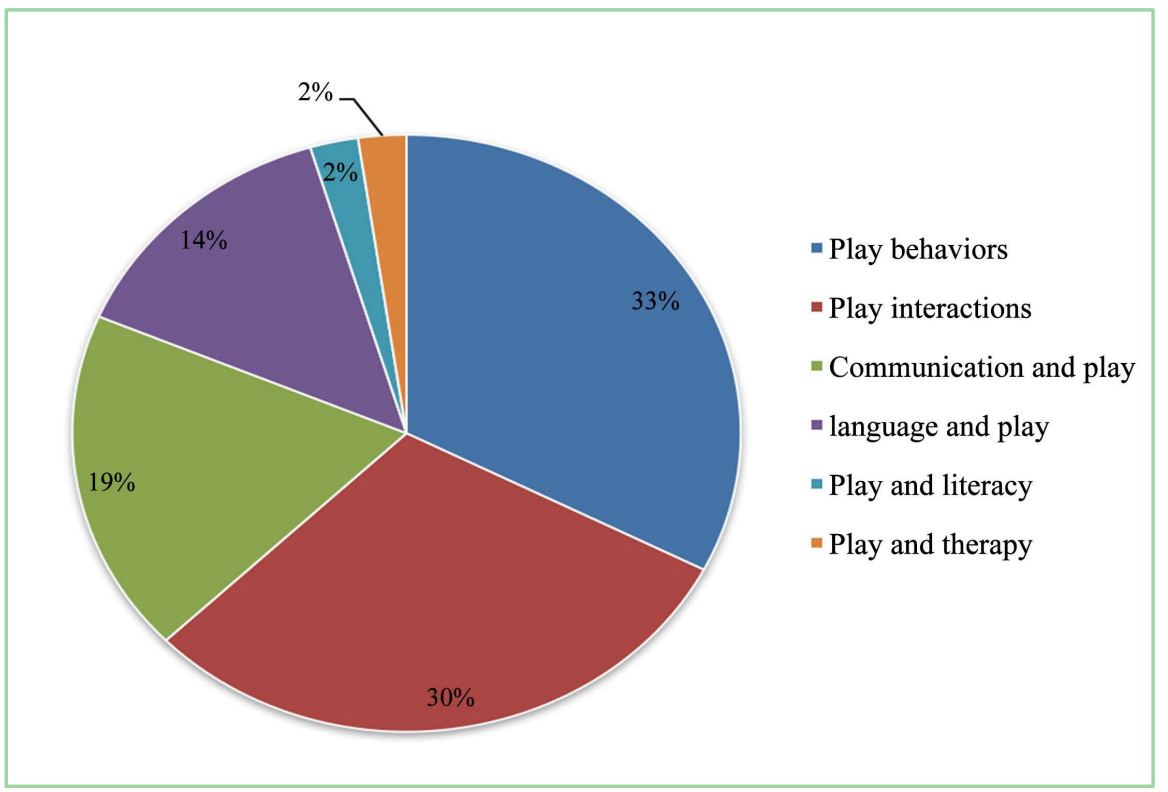

Figure 5. Frequency on research focus.

focused on developing literacy skills (Pataki, Metz, \& Metz, 2014, Quittner et al., 2016) and one that focused on the use of play for therapy purposes (Chapel, 2005).

\subsection{Language, Literacy, and Play}

Play in ECE programs is a tool to support language and literacy development. The only one study that focused on the use of children play in developing literacy skills reported its effect of on students' storybook reading skills (Pataki, Metz, \& Metz, 2014). The review noted there were limited studies that explored language, and play of children who are deaf (Casby \& McCormack, 1985; Cornelious \& Hornett, 1990; Lederberg, 1991; Musyoka, 2015; Quittner et al., 2016; Schirmer, 1989). Casby and McCormack (1985) study reported a relationship between language and symbolic play among deaf children.

Cornelious and Hornett (1990) noted that language and play of children who are deaf varied with the play context. In Lederberg (1991) study children with high language ability were observed to engage in triadic interactions with teachers and other peers and preferred play partners with similar language ability. A 
more recent play by Quittner et al. (2016) found that children who had early implantation had early access to spoken language which impacted their symbolic play and novel noun learning. There were only two studies that occurred in an ASL English bilingual play environment (Musyoka, 2015a, b). Musyoka's (2015a) study echoed the findings by Lederberg (1991) that the play partners influenced the use of language during play. Contrarily, Musyoka's (2015b) findings conflicted previous findings on the social and cognitive play behaviors of a deaf child. In Musyoka's study, the deaf child in a bilingual program demonstrated similar behaviors as those reported in research with hearing children. Earlier studies had reported low social and cognitive play behaviors.

\section{Discussion, Conclusion, and Future Implications}

The earliest studies that focused on the play of children who are deaf dated back to 1970s (Arnold \& Tremblay, 1979; Brackett \& Henniges, 1976; Darbyshire, 1977; Kretschmer, 1972). Among hearing children, although there is evidence of research on children play as early as the 1920s and 1930s (Bott, 1928; Green, 1933; Parten, 1933), the 1970s were a prolific period regarding research on children's play (Sutton-Smith, 1983). This suggests there was a delay in investigating play of children who are deaf. The delay in research on deaf children may explain why most research on deaf children's play employed comparative research methodologies. The choice of comparative research methodology is noted in several studies that examined play of children with special needs (Merry, 1933; Singer \& Streiner, 1966; Cowan, 1972). Therefore, previous research interest on children with special needs was not to understand the children's play behaviors but to understand how they deviated from their peers who were considered the "norm".

The majority of the research in this review focused on social aspects, and cognitive aspects observed in play behaviors of children who are deaf. Only one study focused on literacy development (Pataki, Metz, \& Metz, 2014). The absence of research on play and literacy among children who are deaf is unexpected finding because play in ECE has not only been associated with the whole child's development but with the development of literacy skills. Also, the absence deviates from what was observed in earlier studies of young hearing children's play that examined literacy skills within play context (Cook 2000; Johnson, Christie, \& Wardle 2005; Gmitrova \& Gmitrova, 2003; Pederson, Rook-Green, \& Elder, 1981; Pellegrini, 1980; Saltz, Dixon, \& Johnson, 1977; Saracho, 2001, 2004; Yawkey, 1981; Wolfgang, 1974). In fact, as early as 1983 there was a compiled review of literature that focused on play as a vehicle for developing literacy in young children (Isenberg \& Jacob, 1983).

Although previous research showed interplay of language, cognition and social interaction such as play (Connolly, Doyle, \& Reznick, 1988; McCune-Nicolich, 1995; McCune-Nicolich, 1981; Piaget, 1962), the current review noted a lack of research on the play where language access and use were considered critical. In 
most of the studies examined reference was made to the type of communication system the students used as opposed to their language ability and use. Since deaf students can either access language using an auditory modality or visually modality or bimodal, there is a need for studies that address how students access language, their language ability and the nature of play observed.

\section{Conflicts of Interest}

The authors declare no conflicts of interest regarding the publication of this paper.

\section{References}

Allen, T. (1986). Patterns of Academic Achievement among Hearing Impaired Students: 1944 and 1983. In Karchmer (Ed.), Deaf Children in America (pp. 161-206). Boston: Little Brown.

Allen, T. E., Letteri, A., \& Choi, S. H. (2014). American Annals of the Deaf, 159, 346-358. https://doi.org/10.1353/aad.2014.0030

Arnold, D., \& Tremblay, A. (1979). Interaction of Deaf and Hearing Preschool Children. Journal of Communication Disorders, 12, 245-251. https://doi.org/10.1016/0021-9924(79)90045-5

Ashiabi, G. S. (2007). Play in the Preschool Classroom: Its Socioemotional Significance and the Teacher's Role in Play. Early Childhood Education Journal, 35, 199-207.

https://doi.org/10.1007/s10643-007-0165-8

Bergen, D. (2002). The Role of Pretend Play in Children's Cognitive Development. Early Childhood Research \& Practice, 4, 1-13.

Bergen, D., \& Mauer, D. (2000). Symbolic Play, Phonological Awareness, and Literacy Skills at Three Age Levels. In K. A. Roskos, \& J. F. Christie (Eds.), Play and Literacy in Early Childhood: Research from Multiple Perspectives (pp. 45-62).

Bilir, S., \& Bal, S. (1995). A Study on Social Communication Behavior of 5 to 7-Year-Old Kindergarten Children with Profound Hearing Loss in Integrational Situations. In A. Weisel (Ed.), Proceedings of the $18^{\text {th }}$ International Congress of the Education of the Deaf (pp 368-378). Tel Aviv: Ramot.

Bobzien, J., Richels, C., Raver, S. A., Hester, P., Browning, E., \& Morin, L. (2013). An Observational Study of Social Communication Skills in Eight Preschoolers with and without Hearing Loss during Cooperative Play. Early Childhood Education Journal, 41, 339-346. https://doi.org/10.1007/s10643-012-0561-6

Brackett, D., \& Henniges, M. (1976). Communicative Interaction of Preschool Hearing Impaired Children in an Integrated Setting. The Volta Review, 78, 276-285.

Bredekamp, S., \& Copple, C. (1997). Developmentally Appropriate Practice in Early Childhood Programs (rev. ed.). Washington, DC: NAEYC.

Brown, P. M., Prescott, S. J., Rickards, F. W., \& Paterson, M. M. (1997). Communicating about Pretend Play: A Comparison of the Utterances of 4-Year-Old Normally Hearing and Deaf or Hard-of-Hearing Children in an Integrated Kindergarten. Volta Review, 99, 5-17.

Brown, P. M., Prescott, S. J., Rickards, F. W., \& Paterson, M. M. (1997). Communicating about Pretend Play: A Comparison of the Utterances of Four-Year-Old Normally Hearing and Deaf or Hard of Hearing Children in an Integrated Kindergarten. The Volta Review, 99, 5-18.

Brown, P. M., Remine, M. D., Prescott, S. J., \& Rickards, F. W. (2000). Social Interactions 
of Preschoolers with and without Impaired Hearing in Integrated Kindergarten. Journal of Early Intervention, 23, 200-211. https://doi.org/10.1177/10538151000230030901

Brunnberg, E. (2005). The School Playground as a Meeting Place for Hard of Hearing Children. Scandinavian Journal of Disability Research, 7, 73-90. https://doi.org/10.1080/15017410510032163

Casby, M. W., \& McCormack, S. M. (1985). Symbolic Play and Early Communication Development in Hearing-Impaired Children. Journal of Communication Disorders, 18, 67-78. https://doi.org/10.1016/0021-9924(85)90016-4

Chapel, S. L. (2005). Child-Centered Play Therapy with Deaf Children: Exploring Linguistic and Cultural Implications. Counselor Education Master's Theses, Paper 20, The College at Brockport.

Cheng, P.-W. (2012). The Relation between Early Childhood Teachers' Conceptualization of "Play" and Their Practice: Implication for the Process of Learning to Teach. Frontiers of Education in China, 7, 65-84. https://doi.org/10.1007/BF03396935

Christakis, D. A., Zimmerman, J. F., \& Garrison, M. M. (2007). Effect of Block Play on Language Acquisition and Attention in Toddlers: A Pilot Randomized Controlled Trial. Archives of Pediatrics \& Adolescent Medicine, 161, 967-971. https://doi.org/10.1001/archpedi.161.10.967

Christie, J. F., \& Enz, B. (1992). The Effects of Literacy Play Interventions on Preschooler's' Play Patterns and Literacy Development. Early Education and Development, 3, 205-220. https://doi.org/10.1207/s15566935eed0303_1

Connolly, J. A., Doyle, A., \& Reznick, E. (1988). Social Pretend Play and Social Interaction in Preschoolers. Journal of Applied Psychology, 9, 301-313. https://doi.org/10.1016/0193-3973(88)90032-9

Cook, D. (2000). Voice Practice: Social and Mathematical Talk in Imaginative Play. Early Child Development and Care, 162, 51-63. https://doi.org/10.1080/0300443001620105

Cornelius, G., \& Hornett, D. (1990). The Play Behavior of Hearing-Impaired Kindergarten Children. American Annals of the Deaf, 135, 316-321. https://doi.org/10.1353/aad.2012.0542

Cowan, M. K. (1972). Sex Role Typing in the Blind Child as Measured by Play Activity Choices. American Journal of Occupational Therapy, 26, 85-87.

Creswell, J. W. (2012). Research Design: Qualitative, Quantitative, and Mixed Methods Approaches. Thousand Oaks, CA: Sage Publications.

Darbyshire, J. O. (1977). Play Patterns in Young Children with Impaired Hearing. Volta Review, 79, 19-26.

DeLuzio, J., \& Girolametto, L. (2011). Peer Interactions of Preschool Children with and without Hearing Loss. Journal of Speech, Language, and Hearing Research, 54, 1197-1210. https://doi.org/10.1044/1092-4388(2010/10-0099)

Esposito, B. G., \& Koorland, M. A. (1989). Play Behavior of Hearing Impaired Children: Integrated and Segregated Settings. Exceptional Children, 55, 412-419. https://doi.org/10.1177/001440298905500504

Fisher, K., Hirsh-Pasek, K., Golinko, M. R., Singer, G. D., \& Berk, L. (2009). Playing around in School: Implications for Learning and Educational Policy. In A. D. Pellegrini (Ed.), The Oxford Handbook of the Development of Play (pp. 341-62). New York, NY: Oxford University Press.

Freel, B. L. Clark, M. D., Anderson, M. L., Gilbert, G., Musyoka, M. M., \& Häuser, P C. (2011). Deaf Individuals' Bilingual Abilities: American Sign Language Proficiency, Reading Skills, and Family Characteristics. Psychology, 2, 18-23. 
https://doi.org/10.4236/psych.2011.21003

Furth, H. G. (1966). A Comparison of Reading Test Norms of Deaf and Hearing Children. American Annals of the Deaf, 111, 461-462.

Gatty, J. C. (1990). The Effect of Deafness on Play in Four-Year-Old Boys. Unpublished Dissertation, Amherst, MA: University of Massachusetts.

Gmitrova, V., \& Gmitrova, J. (2003). The Impact of Teacher-Directed and Child Directed Pretend Play on Cognitive Competence in Kindergarten Children. Early Childhood Education Journal, 30, 241-246. https://doi.org/10.1023/A:1023339724780

Golos, D. B., \& Moses, A. M. (2013). Developing Preschool Deaf Children's Language and Literacy Learning from an Educational Media Series. American Annals of the Deaf, 158, 411-425. https://doi.org/10.1353/aad.2013.0039

Gray, C. D. (1995). Helping Deaf Children towards Literacy during Their Primary School Years: Which Skills Should We Be Fostering? Journal of the British Association of Teachers of the Deaf, 19, 22-37.

Higginbotham, D. J., \& Baker, B. M. (1981). Social Participation and Cognitive Play Differences in Hearing Impaired and Normally Hearing Preschoolers. The Volta Review, 83, 135-149.

Isenberg, J., \& Jacob, E. (1983). Literacy and Symbolic Play: A Review of the Literature. Childhood Education, 59, 272-276.

Jamaludin, K. A., Alias, N., \& DeWitt, D. (2015). Research and Trends in the Studies of Homeschooling Practices: A Review on Selected Journals. Turkish Online Journal of Educational Technology, 14, 111-119.

Johnson, E., Christie, J. F., \& Wardle, F. (2005). Play, Development and Early Education. Boston: Pearson.

Kretschmer, R. (1972). A Study to Assess the Play Activities and Gesture Output of Hearing Handicapped Preschool Children. Cincinnati Speech and Hearing Center: U.S. Department of Health, Education, and Welfare, Office of Education, Bureau of the Handicapped, Project No.45-2109.

Lederberg, A. R. (1991). Social Interaction among Deaf Preschoolers: The Effects of Language Ability and Age. American Annals of the Deaf, 136, 53-59.

https://doi.org/10.1353/aad.2012.0507

Lederberg, A. R., Ryan, H. B., \& Robbins, B. L. (1986). Peer Interaction in Young Deaf Children: The Effect of Partner Hearing Status and Familiarity. Developmental Psychology, 22, 691. https://doi.org/10.1037/0012-1649.22.5.691

Lee, J. S. (2006). Preschool Teachers' Shared Beliefs about Appropriate Pedagogy for 4-Year-Olds. Early Childhood Education Journal, 33, 433-441. https://doi.org/10.1007/s10643-006-0059-1

Levine, L. M. (1993). The Play Patterns of Young Hearing-Impaired Children with Their Hearing and Hearing-Impaired Peers. Unpublished Doctoral Dissertation, Arizona: University of Arizona.

Levy-Shiff, R., \& Hoffman, M. A. (1985). Social Behavior of Hearing-Impaired and Normally-Hearing Preschoolers. British Journal of Educational Psychology, 55, 111-118. https://doi.org/10.1111/j.2044-8279.1985.tb02615.x

Lynch, M. (2015). More Play, Please: The Perspective of Kindergarten Teachers on Play in the Classroom. American Journal of Play, 7, 347-370.

Mann, L. F. (1984). Play Behaviors of Deaf and Hearing Children. In D. S. Martin (Ed.), International Symposium on Cognition, Education, and Deafness (pp. 27-32). Washington DC. 
Maschi, T., Baer, J., \& Turner, S. G. (2011). The Psychological Goods on Clinical Social Work: A Content Analysis of the Clinical Social Work and Social Justice Literature. Journal of Social Work Practice, 25, 233-253. https://doi.org/10.1080/02650533.2010.544847

Mayer, C. (2007). What Really Matters in the Early Literacy Development of Deaf Children. Journal of Deaf Studies and Deaf Education, 2, 411-431. https://doi.org/10.1093/deafed/enm020

McCune-Nicholich, L. (1981). Toward Symbolic Functioning: Structure of Early Pretend Games and Potential Parallels with Language. Child Development, 52, 785-797. https://doi.org/10.1111/j.1467-8624.1981.tb03115.x

McCune-Nicolich, L. (1995). A Normative Study of Representational Play at the Transition to Language. Developmental Psychology, 31, 198-120. https://doi.org/10.1037/0012-1649.31.2.198

McKirdy, L. S., \& Blank, M. (1982). Dialogue in Deaf and Hearing Preschoolers. Journal of Speech, Language, and Hearing Research, 25, 487-499. https://doi.org/10.1044/jshr.2504.487

Merry, F. K. (1933). Judging Personality Adjustments of Blind Kindergarten Children through Play Activities. Teachers Forum, 5, 86-95.

Messenheimer-Young, T., \& Kretschmer, R. R. (1994). Can I Play? A Hearing-Impaired Preschooler's Requests to Access Maintained Social Interaction. The Volta Review, 95, 5-18.

Minnett, A., Clark, K., \& Wilson, G. (1994). Play Behavior and Communication between Deaf and Hard of Hearing Children and Their Hearing Peers in an Integrated Preschool. American Annals of the Deaf, 139, 420-429.

https://doi.org/10.1353/aad.2012.0345

Mitchell, R. E., \& Karchmer, M. A. (2004). Chasing the Mythical Ten Percent: Parental Hearing Status of Deaf and Hard of Hearing Students in the United States. Sign Language Studies, 4, 138-163. https://doi.org/10.1353/sls.2004.0005

Moores, D. (1987). Educating the Deaf: Psychology, Principles, and Practices. Boston, MA: Houghton Mifflin.

Musyoka, M. (2015b). American Sign Language, Peer Play, and the Deaf Child: A Case Study of Ann. Psychology, 6, 1822-1831. https://doi.org/10.4236/psych.2015.614178

Musyoka, M. M. (2015a). Understanding Indoor Play in Deaf Children: An Analysis of Play Behaviors. Psychology, 6, 10-19. https://doi.org/10.4236/psych.2015.61002

Myers, C., Clark, M., Musyoka, M., Anderson, M., Gilbert, G., Agyen, S., \& Hauser, P. (2010). Black Deaf Individuals' Reading Skills: Influence of ASL, Culture, Family Characteristics, Reading Experience, and Education. American Annals of the Deaf, 155, 449-457. https://doi.org/10.1353/aad.2010.0044

NAEYC (2009). Developmentally Appropriate Practice in Early Childhood Programs Serving Children from Birth through Age 8. Position Statement. http://www.naeyc.org/les/naeyc/le/positions/PSDAP.pdf

O'Connor, W. L. (1994). Characteristics of Socio Dramatic Play of Hard of Hearing Children in Relation to Language Development. York University.

Onwuegbuzie, A. J., Leech, N. L., \& Collins, K. M. T. (2012). Qualitative Analysis Techniques for the Review of the Literature. The Qualitative Report, 17, 1-28. http://www.nova.edu/ssss/QR/QR17/onwuegbuzie.pdf

Parten, M. B. (1933). Social Play among Preschool Children. Journal of Abnormal and Social Psychology, 28, 136-147. https://doi.org/10.1037/h0073939 
Pataki, K. W., Metz, A. E., \& Pakulski, L. (2014). The Effect of Thematically Related Play on Engagement in Storybook Reading in Children with Hearing Loss. Journal of Early Childhood Literacy, 14, 240-264. https://doi.org/10.1177/1468798413480516

Pederson, D. R., Rook-Green, A., \& Elder, J. L. (1981). The Role of Action in the Development of Pretend Play in Young Children. Developmental Psychology, 17, 756-759. https://doi.org/10.1037/0012-1649.17.6.756

Pelegrini, A. D. (1980). The Relationship between Kindergartners' Play and Achievement in Prereading, Language, and Writing. Psychology in the Schools, 17, 530-535. https://doi.org/10.1002/1520-6807(198010)17:4<530::AID-PITS2310170419>3.0.CO;2A

Piaget, J. (1962). Play, Dreams and Imitation in Childhood. New York, NY: Norton.

Quance, A., Leher, S. J., \& Stathopoulos, H. (2008). Play in the Grade One Classroom: An Exploration of Teacher Beliefs, Classroom Organization, and Obstacles to Implementation in Quebec. Canadian Journal for New Scholars in Education, 1, 1-18.

Quintas, T. D. Á., Curti, L. M., Goulart, B. N. G. D., \& Chiari, B. M. (2009). Characterization of Symbolic Play in Deaf Children: Case and Control Studies. Pró-Fono Revista de Atualização Científica, 21, 303-308. https://doi.org/10.1590/S0104-56872009000400007

Quittner, A. L., Cejas, I., Wang, N. Y., Niparko, J. K., \& Barker, D. H. (2016). Symbolic Play and Novel Noun Learning in Deaf and Hearing Children: Longitudinal Effects of Access to Sound on Early Precursors of Language. PLOS ONE, 11, e0155964. https://doi.org/10.1371/journal.pone.0155964

Saltz, E., Dixon, D., \& Johnson, H. (1977). Training Disadvantaged Preschoolers on Various Fantasy Activities: Effects on Cognitive Functioning and Impulse Control. Child Development, 48, 367-380. https://doi.org/10.2307/1128629

Saracho, O. N. (2001). Exploring Young Children Literacy Development though Play. Early Child Development and Care, 167, 103-114. https://doi.org/10.1080/0300443011670109

Saracho, O. N. (2004). Literacy and Language Development: Supporting Literacy Related Play: Roles for Teachers of Young Children. Early Childhood Education, 31, 201-206. https://doi.org/10.1023/B:ECEJ.0000012138.07501.44

Schirmer, B. R. (1989). Relationship between Imaginative Play and Language Development in Hearing-Impaired Children. American Annals of the Deaf, 134, 219-222. https://doi.org/10.1353/aad.2012.0609

Singer, J. L., \& Streiner, B. F. (1966). Imaginative Content in the Dreams and Fantasy Play of Blind and Sighted Children. Perceptual and Motor Skills, 22, 475-482. https://doi.org/10.2466/pms.1966.22.2.475

Sisco, F. H., Kranz, P. L., Lund, N. L., \& Scwartz, G. C. (1979). Developmental and Compensatory Play: A Means of Facilitating Social, Emotional Cognitive and Linguistic Growth in Deaf Children. American Annals of the Deaf, 137, 416-417.

Smith, P. K. (2010). Children and Play. West Sussex: Wiley-Blackwell.

Sutton-Smith, B. (1983). One Hundred Years of Changes in Play Research. TAASP Newsletter, 9, 13-17.

Traxler, C. B. (2000). Measuring up to Performance Standards in Reading and Mathematics: Achievement of Selected Deaf and Hard-of-Hearing Students in the National Norming of the Ninth Edition Stanford Achievement Test. Journal of Deaf Studies and Deaf Education, 5, 337-348. https://doi.org/10.1093/deafed/5.4.337

Trybus, R., \& Karchmer, M. (1972). School Achievement Scores of Hearing Impaired Children: National Data on Achievement Status and Growth Patterns. American An- 
nals of the Deaf, 12, 62-69.

Vandell, D. L., \& George, L. B. (1981). Social Interaction in Hearing and Deaf Preschoolers: Successes and Failures in Initiations. Child Development, 52, 627-635. https://doi.org/10.2307/1129183

Vukelich, C. (1994). Effects of Play Interventions on Young Children's Reading of Environmental Print. Early Childhood Research Quarterly, 9, 153-170. https://doi.org/10.1016/0885-2006(94)90003-5

Weisbert, D. S., Zosh, J. M., Hirsh-Pasek, K., \& Golinkoff, R. M. (2013). Talking It up: Play, Language Development, and the Role of Adult Support. American Journal of Play, 6, 39-54.

Williams, C. (2004). Emergent Literacy of Deaf Children. Journal of Deaf Studies and Deaf Education, 9, 352-365. https://doi.org/10.1093/deafed/enh045

Williams, C. L. (1991). The Verbal Language Worlds and Early Childhood Literacy Development of Three Profoundly Deaf Preschool Children. Unpublished Doctoral Dissertation, Columbus, $\mathrm{OH}$ : Ohio State University.

Williams, C. L., Kantor, R., \& Pinnell, S. G. (1992). The Language and Literacy Worlds of Profoundly Deaf Preschool Children: Informing Developmental Theory.

Wolfgang, C. H. (1974). An Exploration of the Relationship between the Cognitive Area of Reading and Selected Developmental Aspects of Children Play. Psychology in the Schools, 11, 338-343.

https://doi.org/10.1002/1520-6807(197407)11:3<338::AID-PITS2310110319>3.0.CO;2$\underline{\mathrm{T}}$

Yawkey, T. D. (1981). Sociodramatic Play Effects on Mathematical Learning and Adult Ratings of Playfulness in Five Year Olds. Journal of Research and Development in Education, 527-533.

Zainuddin, Z., \& Halili, S. H. (2016). Flipped Classroom Research and Trends from Different Fields of Study. International Review of Research in Open and Distributed Learning, 17, 313-340. https://doi.org/10.19173/irrodl.v17i3.2274 